\title{
THE CORRELATION BETWEEN READING MOTIVATION AND READING COMPREHENSION OF THE GRADE X STUDENTS SMA S NURUL 'ILMI PADANGSIDIMPUAN
}

\author{
BY \\ Desti Amelisa Gultom, S.Pd \\ Eka Sustri Harida, M.Pd, Fitri Rayani, M.Hum
}

\begin{abstract}
ABSTRAK
Penelitian ini bertujuan untuk mencari korelasi antara motivasi membaca dan pemahaman membaca siswa di kelas X SMA S Nurul Ilmi Padangsidimpuan. Penelitian ini menggunakan metode kuantitaif dengan metode korelasi. Populasi nya terdiri dari 240 siswa dari delapan kelas. Kemudian sample diambil dengan random sebanyak 48 siswa. Data dikumpulkan melalui angket untuk mengetahui motivasi membaca siswa dan tes untuk mengetahui pemahaman membaca siswa serta menggunakan product moment dan t-test untuk menganalisis data. Hasil dari penelitian ini ditemukan rata-rata skor motivasi membaca siswa adalah 93 dan rata-rata skor pemahaman membaca adalah 65.66. Skor pada $r_{\text {count }}$ adalah 0.474 dan $r_{\text {table }}$ pada taraf significant $5 \%$ adalah 0.368 . Hasilnya $r_{\text {count }}$ lebih besar dari $\mathrm{r}_{\text {table }}(0.474>0.368)$. Kemudian, skor dari $\mathrm{t}_{\text {count }}$ adalah 3.692 dan $\mathrm{t}_{\text {table }}$ pada taraf significant $1 \%$ adalah 2.09. Jadi, $t_{\text {count }}$ lebih besar dari $t_{\text {table }}(3.692>2.09)$ yang berarti hipotesis $\left(\mathrm{H}_{\mathrm{a}}\right)$ diterima. Peneliti menyimpulkan bahwa signifikan korelasi antara motivasi membaca dan kemampuan membaca siswa kelas $\mathrm{X}$ di SMA $\mathrm{S}$ Nurul Ilmi Padangsidmpuan adalah kategori cukup.
\end{abstract}

Keywords: motivasi membaca, pemahaman membaca

\section{A. INTRODUCTION}

In academic field, the students are required to master the four skills of English, such as reading, listening, writing and speaking. Each skill cannot be separated, it should been comprehensive. To create a successful learning, the students should learn each skill, reading skill which is regarded as one of the important. It can be said that reading skill is very useful for academic success. Reading also plays important role in many aspects of life. Since much of information or literature is still written in English so that reading skill is very important and it is needed in comprehending the texts. It is not only important to those who are studying in school or college, but also for people who are not students there anymore.

Reading is an interaction between readers to the text. Reading is important to be learned and mastered by every human. The process in reading happens when a reader 
tryes to communicate with a writer through their writing, they try to understand to the text well. Reading is as a medium of language learning. It means that every aspect of learning reading as a largest component and it is also influence the learning process that dominantly by reading.

Reading comprehension is important skill that should be mastered by students beside the three other skills. By reading, students will get information from the printed material or electronic form. The information will help students to comprehend the other reading and it can be as a reference and background knowledge. Then, through reading students can add vocabularies to find meaning of word and it will make students easy to comprehend written or spoken. Next, reading can enrich their experience, knowledge, and improve their critical thinking. In addition, reading can increase their focus and concentration. They can train their brain to focus and concentration more on their read and to focus on learning process. Many factors that affect reading process include reading interest, reading strategies, reading habit, reading motivation and etc. in this research just focus about reading motivation.

Motivation is mental encouragement as an activator to do something. By having motivation students will get more enthusiasm in doing action. Motivation is also an interest of the students in learning and wants of the students in learning. The students who have low motivation will be unsuccessful in learning. Because having low motivation makes the students are not interested in learning. ${ }^{1}$ The Students with low motivation will get low achievement also in their skill such writing skill, speaking skill, listening skill and reading skill. Motivation for students is a main element that affects theory reading comprehension. However, it has not been yet recognized that motivation is main factor in reading comprehension. In this research, the researcher focuses to discuss students' reading motivation.

Reading motivation is one of the main factors foreign language students that help learners to read more effectively. ${ }^{2}$ If students have motivation in reading, it will make them more focus in reading and help them easier to comprehend books or electronic form. Reading motivation will give spirit or support for students to comprehend a text well. So, reading motivation one of the most important factors to make students successful in reading comprehension.

\footnotetext{
${ }^{1}$ Robert. E. Slavin, Educational Psychology: Theory and Practice, $8^{\text {th }}$ Edition (New York: Pearson Education, Inc, 2006), p. 347.

${ }^{2}$ Seymour, S., \& Walsh, L. Essential of Teaching Academic Reading (Boston: Houghton Miflin Harcourt, 2006).
} 
Based on interview of the researcher to the English teacher in SMA S Nurul 'IlmiPadangsidimpuan, students have some problems in learning English. ${ }^{3}$ The first, they have lack vocabulary mastery, it makes they have difficulties in each the English aspect such as in grammar skill, writing skill, speaking skill, listening comprehension and especially in reading comprehension. As Putri found that to make students mastered in speaking, they have to know many vocabularies. ${ }^{4}$ Vocabulary is the important element in language included written or spoken. Many strategies to improve students' vocabulary mastery, one of strategy who English teacher in SMA S Nurul 'IlmiPadangsidimpuan has applied there to improve their vocabulary mastery is by memorizing of some vocabulary before learning process.

The second, they have low motivation on learning English, because English not their mother tongue. As Ade found that there is correlation between motivation (extrinsic motivation) and English achievement. ${ }^{5}$ They Learn English as demands of curriculumthat make them must learn English. But, when the teacher gives some reading text, most of them have

good reading comprehension and some of them also till have low reading comprehension. Many efforts have done by English teacher to improve students' motivation in reading, such as giving advices about reading is really useful for the life, the learning process and convince that by reading more of English text will more easy to comprehend some kind of text.

The third, they have difficulties in grammar. Grammar is language system that arranges English language structure. It is the important element to arrange the sentence in English. ${ }^{6}$ Much effects of grammar toward students' English skill. As Ita found that grammar affect student's ability in reading descriptive text. ${ }^{7}$ The first effect, by grammar students will produce the good sentence in English in writing. Then, Grammar makes student easy to comprehend and get information from the text, because they have

\footnotetext{
${ }^{3}$ Private Interviewwith Mrs. Ade Purnama, the English teacher of the grade X students (on September, 20 ${ }^{\text {th }} 2017$, at 14.30).

${ }^{4}$ PutriMuliani, The Correlation between Vocabulary Mastery and Speaking Mastery at XI Grade Students of SMA S Nurul'Ilmi Padangsidimpuan, Unpublished Thesis, (Padangsidimpuan: IAIN, 2016).

${ }^{5}$ Ade Purnama, The Correlation Between Extrinsic Motivation and English Achievement at the Eighth Grade Students of SMP N 2 Padangsidimpuan, Unpublished Thesis, (Padangsidimpuan: IAIN, 2017).

${ }^{6}$ SatrioNugroho, Practical English Grammar; Tata BahasaInggrisLengkap (Surabaya: Kartika, 1998), p. 11.

${ }^{7}$ ItaPurnama Sari, The Effect Grammar Transalation Method on Student's Ability in Reading Descriptive Text at Grade X of SMAN 1 Arse, Unpublished Thesis, (Padangsidimpuan: IAIN, 2015).
} 
understood of the language system in English. So, there is correlation between grammar and students' reading comprehension.

To be successful in reading, motivation is one of the important factors. The reasons why motivation is important factor of students' successful in reading is that motivation has close relation with students in comprehending a text, and students need to have motivation in reading. If the students have motivation to read, then students will be more active in reading. In addition, by having the motivation to read, they can understand and comprehend reading text well.

Based on the above explanation the researcher gets interested in discussing aboutthe reading motivation and the relationship to reading comprehension of the grade $\mathrm{X}$ students SMA S Nurul 'Ilmipadangsidimpuan.

\section{B. THE LITERATURE REVIEW}

\section{Reading Comprehension}

Reading comprehension is very important to have, because comprehension is the process of reader to understand the written language. There are some functions of comprehension such as: 1. to understand the text easier, 2. to image what the information in content, 3. to follow the construct of a passage, 4. to recognize a researcher purpose, attitude, tone and mood. ${ }^{8}$ It means comprehension can't be separated in reading process because you must make a sense from the text to get the information. So, Reading Comprehension is an ability to understand what the readers read where words have contexts and texts have meaning.

Reading comprehension needs theories and steps to get it. There are three ways to process and comprehend the text. They are bottom-up processing, topdown processing, and interactive processing.

When students read, it is for a purpose. Jordan figures that students can have different purposes in their reading, these are included:

1) To obtain the information (fact, data, etc).

2) To understand ideas or theories, etc.

3) To discover authors' viewpoints.

4) To seek evidence for needed for their own point of view and to quote all of which may be needed for writing their essays, etc. ${ }^{9}$

${ }^{8}$ David Nunan, Practical English......., p. 68.

${ }^{9}$ R. R. Jordan, English for Academic......., p. 143. 
The goal of reading is to comprehend; the comprehension is to get information. In reading process, the readers need strategies to get faster and appropriate information. Strategy is the way to achieve the goal of something. So, everybody can choose the best strategy based on their selves.

There are some indicators in assessing students' reading comprehension, ${ }^{10}$ as follow:

Table 1

Indicators of Reading Comprehension

\begin{tabular}{|c|l|}
\hline NO & \multicolumn{1}{|c|}{ Indicators of Reading Assessment } \\
\hline $\mathbf{1}$ & Able to identify the main idea of the text \\
\hline $\mathbf{2}$ & Able to identify specific information of the text \\
\hline $\mathbf{3}$ & Able to identify detail information of the text \\
\hline $\mathbf{4}$ & Able to get the meaning of the text (words or sentences) \\
\hline
\end{tabular}

\section{Reading Motivation}

Reading motivation is crucial for children to develop their reading skill. It is an important factor which supports students to read more, and it has a significant relationship with reading and understanding text. ${ }^{11}$ Reading motivation is an important factor which supports students to read more, and it has a significant relationship with reading and understanding text. Motivation benefits of being a motivated reader by stating that it is important to motivate students to read by providing them opportunities to select their desired materials. ${ }^{12}$ So, students would likely to read more when they are allowed to choose their reading materials because would discover that reading is an enjoyable activity.

Meanwhile, reading motivation is defined by an individual's self-concept and the value of individual places on reading, it can be said students have self

\footnotetext{
${ }^{10}$ Silabus, "Bahasa Inggris-Wajib SMA Kelas X", Kurikulum 2013, (Accessedfromhttps://goo.gl/Vqbqqw, Retrievedon October $21^{\text {th }}, 2017$ ).

${ }^{11}$ Sarah P. McGeown, Reading Motivation Engagement in The Primary School Classroom: Theory, Research and Practice(e-book) (The United Kingdom Literacy Association, 2013), p. 2, Accessed from https://goo.gl/wYX147, Retrieved on November, $6^{\text {th }} 2017$.

${ }^{12}$ Mohammad Reza Ahmadi, "The Correlation Between Students'Reading Motivation and Reading Comprehension", Vol. 4, No.18, 2013, Journal of Educational and Fractice(Accessed from https://goo.gl/h67dfU, Retrieved on September, $26^{\text {th }} 2017$ ).
} 
concept in reading. ${ }^{13}$ It is as factors that lead and drive students' behavior or desire to read. This can be seen from their effort in reading.

Reading motivation included intrinsic motivation and extrinsic motivation. Intrinsic motivation is the desire for change or do something comes from within individual, one aspect of intrinsic motivation becoming totally involved in the activity one is doing. ${ }^{14}$ John W. Santrock said intrinsic motivation is a desire which comes from inside to do something. Intrinsic Motivation involves the internal motivation to do something for its own sake. ${ }^{15}$ So, intrinsic reading motivation is involves the internal motivation to do something for its own sake.

Intrinsic Motivation in reading includes reading involvement, an enjoyment or experiencing different kinds of literary or informational text. The notion of involvement in reading refers to pleasure gained from reading a well-written book or article topic one find interesting, reading importance as reading as an aspect work on subjective. ${ }^{16}$ So, reading motivation comes from students' involvement, an enjoyment. In addition, curiosity and Preference for challenge.

Extrinsic motivation is achievement goal that come from outside the person, it includes reading for recognition the performance goals. ${ }^{17}$ Students with this orientation seek to maximize favorable evaluations of their ability and minimize negative evaluation of ability. The students that have performance goal orientation will like to improve their reading ability. The individual that has this orientation focuses on mastering tasks and increasing competence at different task.

The other aspects of extrinsic reading motivation are reading for competition, the desire to outperform others in reading. These different kinds of motivation reflect the fact that children do much of their reading in school, where their reading performance is evaluated and compared to others' performance, reading for social reasons or the process of constructing and sharing the meaning

\footnotetext{
${ }^{13}$ Linda B. Gambrel and Friends, "Assessing Motivation to Read", Vol. 49, No.7, 519.1996, International Reading Association (Accessed fromhttps://goo.gl/2UFcdD, Retrieved on September, $26^{\text {th }}$ 2017).

${ }^{14}$ ImaHartati,et. al., "The Correlation Between Reading Motivation and Reading Comperehension of the First Year Students of SMK TarunaSatriaPekanBaru" (Accessed fromhttps://goo.gl/28wbJt, retrieved on September, $\left.26^{\text {th }} 2017\right)$, p. 4.

${ }^{15}$ John W. Santrock, Educational Psychology (New York: Mc- Graw Hill, 2004), p. 418.

${ }^{16}$ Ibid.

${ }^{17}$ ImaHartati, et. al., "The Correlation Between ......", p. 4.
} 
gained from reading with friends or family and reading for compliance or reading to meet the expectations of others. ${ }^{18}$ So, the student extrinsic motivation comes from outside because of competition and the desire to outperform others in reading.

\section{THE RESEARCH METHODOLOGY}

The location of this research has been conducted in SMA S Nurul 'IlmiPadangsidimpuan, at BM. Muda Street, Num. 05, Padang Matinggi Lestari, South Padangsidimpuan, North Sumatra. The time of research has been conducted from October 2017 until April 2018. The kind of this research is quantitative research where the method is correlation method.The population of this research was the grade X students SMA S Nurul 'IlmiPadangsidimpuan for about 240 studentsThen, the researcher selected the members randomly from each class where the number of members was selected are $20 \%$ from population for about 48 students. The instruments of this research to collect the data are test and questionnaire.

\section{THE RESULT OF THIE RESEARCH}

\section{Reading Motivation}

The score resume of variable $\mathrm{X}$ that reading motivation of the grade $\mathrm{X}$ students of SMA S Nurul 'IlmiPadangsidimpuan have been calculated, it was gotten that the highest score was 117 and the lowest score was 77 . To complete this research data, the researcher also calculate the mean score was 93, the median score was 118.39, and the mode was 97.66.

In order to get a description of the data clearly and completely, the researcher presents them in histogram on the following figure:

\footnotetext{
${ }^{18}$ Ibid.
} 
Figure 1: Description Data of Students' Reading Motivation

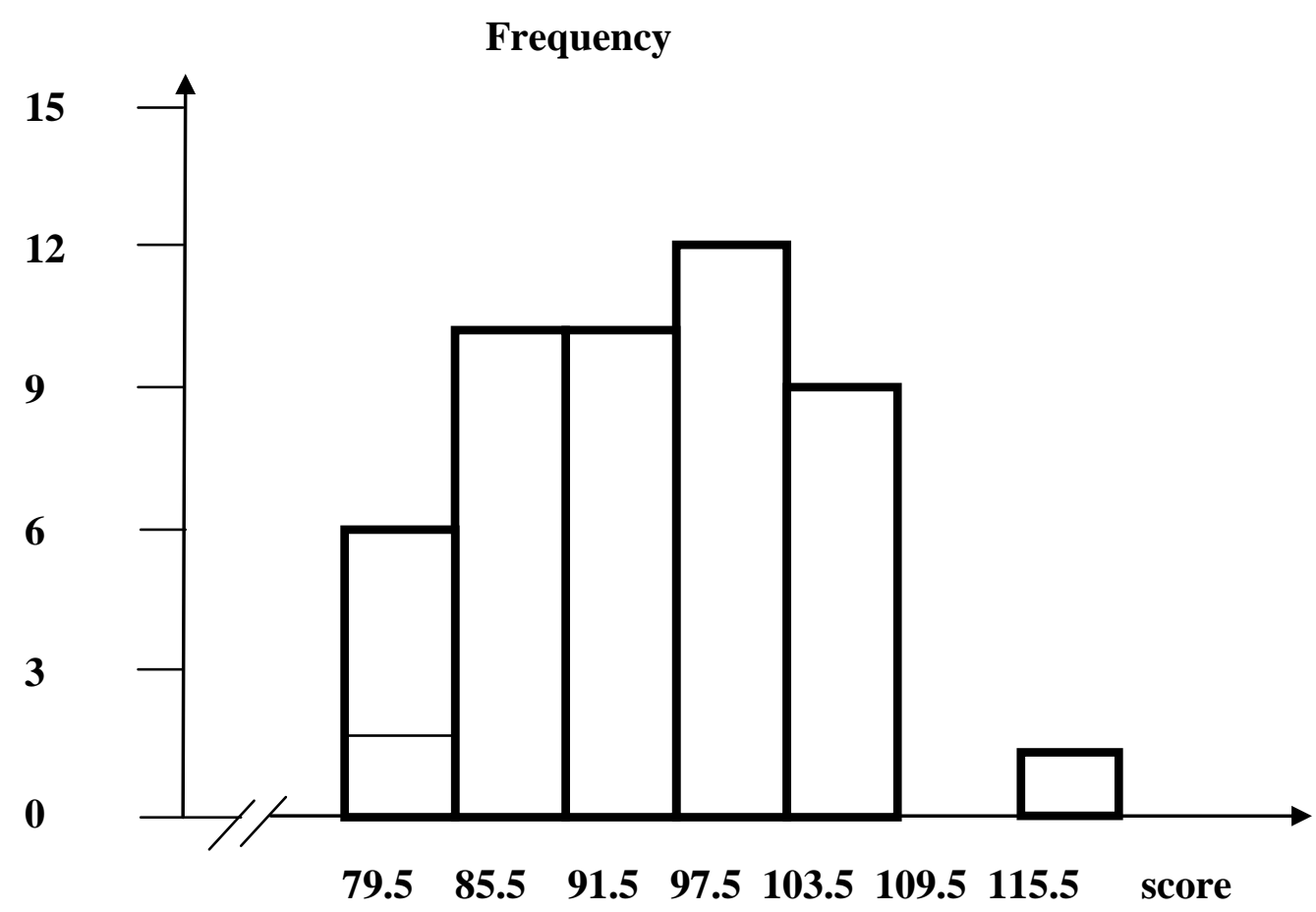

Based on the above chart, it was known that the variable revelation of students' reading motivation showed that the respondent an interval $77-82$ were 6 students (12.5\%), interval $83-88$ were 10 students (20.83\%), interval $89-94$ were 10 students $(20.83 \%)$, interval 95 - 100 were 12 students $(25 \%)$, interval 101- 106 were 9 students (18.76\%), interval 107 - 112 were 0 students (0\%) and last interval $113-118$ were a student $(2.08 \%)$.

\section{Reading Comprehension}

The score resume of variable $\mathrm{Y}$ that students' reading comprehension of the grade X students of SMA S Nurul 'IlmiPadangsidimpuan has been gotten high score was 95, low score was 35 mean score 65.66, median score was 58.39, mode score was 84 (See in appendix 10). The calculation of mean score at students' Reading Comprehension was in enough category. To know the revelation of data was done to group the variable score of reading comprehension which the total classes 7 and interval 9 .

In order to get a description of the data clearly and completely, the researcher presents them in the histogram on the following figure: 
Figure 2: Data Description of Students' Reading Comprehension

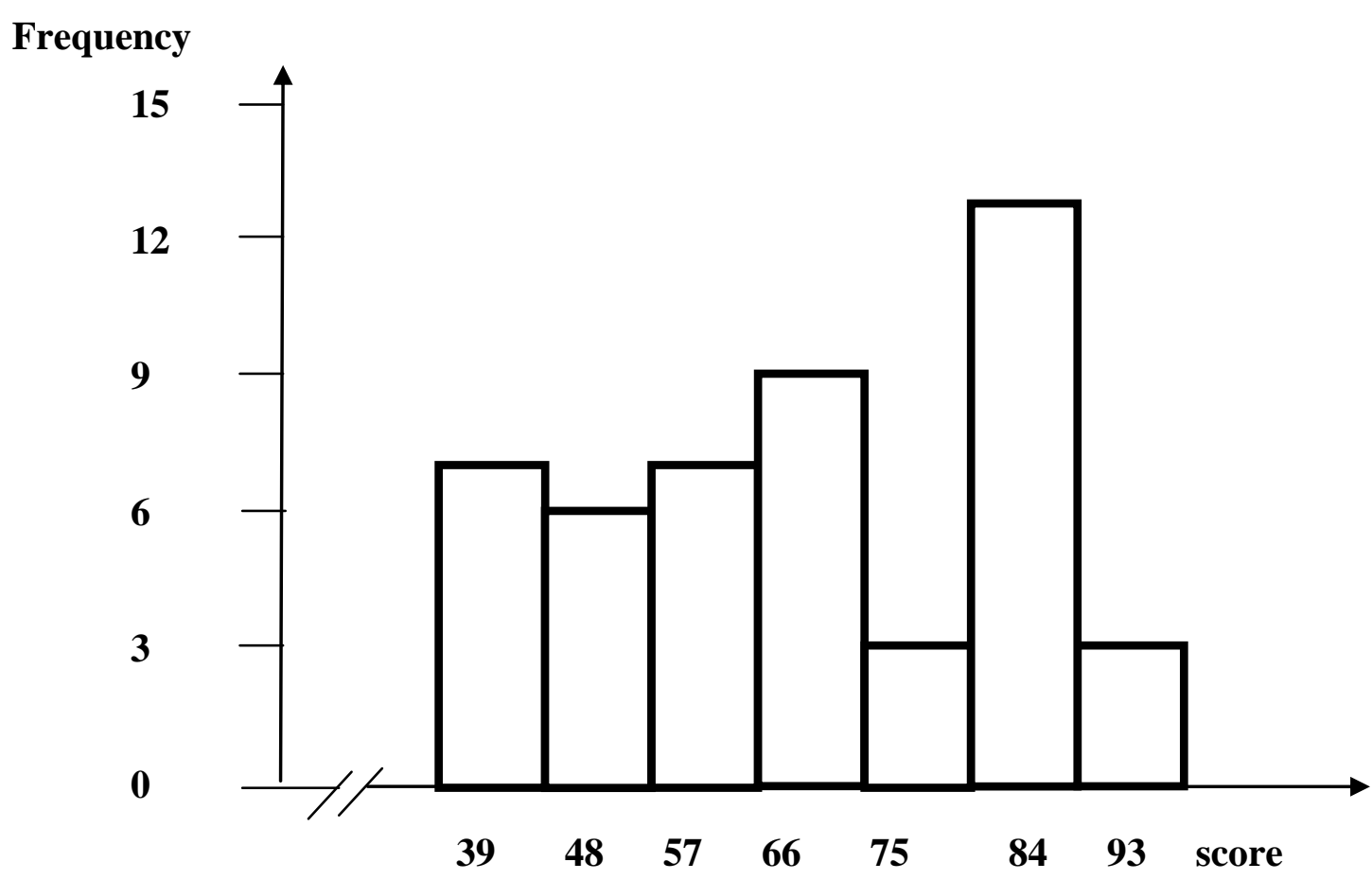

Based on the above table, it was known that the variable revelation of students' reading comprehension showed that the respondent at interval $35-43$ were 7 students $(14.58 \%)$, interval $44-52$ were 6 students $(12.50 \%)$, interval 53 61 were 7 students $(14.58 \%)$, interval 62-70 were 9 students (18.76\%), interval 71 - 79 were 3 students $(6.25 \%)$, interval $80-88$ were 13 students $(27.08 \%)$, the last interval 89 - 97 were 3 students $(6.25 \%)$.

After getting the resume score of variable $\mathrm{X}$ and $\mathrm{Y}$, the data was analyzed by using Chi-Square formula to know the data was normal or not. Normality test was as the requirement of test before go to the testing hypothesis.

\section{Table 1}

Normality of Data X and Data Y

\begin{tabular}{|c|c|c|}
\hline \multirow{2}{*}{ Class } & \multicolumn{2}{|c|}{$\begin{array}{c}\text { Normality } \\
\text { Test }\end{array}$} \\
\cline { 2 - 3 } & $\mathrm{t}_{\text {count }}$ & $\mathrm{t}_{\text {table }}$ \\
\hline Data X & 0.33 & 12.592 \\
\hline Data Y & 8.63 & 12.592 \\
\hline
\end{tabular}


Based on the table above, the score of data $X=x_{\text {count }}^{2}<x_{\text {table }}^{2}(0.33<12.592)$ with $\mathrm{n}=48$ and Data $\mathrm{Y}=\mathrm{x}_{\text {count }}^{2}<\mathrm{x}_{\text {table }}^{2}(8.63<12.592)$ with $\mathrm{n}=48$, on taraf significant $5 \%$. It meant that data $\mathrm{X}$ and $\mathrm{Y}$ were distributed normal.

Before testing the hypothesis, first performed the calculation of the scores obtained by the respondents as the table below:

$$
\begin{aligned}
& \sum \mathrm{X}=4.305 \quad \sum \mathrm{Y}=3.125 \\
& \sum X^{2}=406.987 \quad \sum Y^{2}=220.300 \\
& \sum X Y=289.179
\end{aligned}
$$

By using the values above, calculated the value of correlation between variable $\mathrm{X}$ dan $\mathrm{Y}$ explained below:

$$
\begin{aligned}
r_{\mathrm{xy}} & =\frac{n \sum x y-\left(\sum x\right)\left(\sum y\right)}{\sqrt{n\left\{\sum x^{2}-\left(\sum x\right)^{2}\right\}\left\{n \sum y^{2}-\left(\sum y\right)^{2}\right\}}} \\
& =\frac{48(289179)-(4305)(3125)}{\sqrt{\left\{48 \times 406987-(4305)^{2}\right\}\left\{48 \times 220300-(3125)^{2}\right\}}} \\
& =\frac{13880179-13453125}{\sqrt{\{19535376-18533025\}\{10574400-9765625\}}} \\
& =\frac{427054}{\sqrt{(1002351)(808775)}} \\
& =\frac{427054}{\sqrt{810676025430}} \\
& =\frac{427054}{900375.716} \\
& =0.474
\end{aligned}
$$

Based on the above calculating, the product moment has gotten correlation coefficients $r_{x y}=0.474$ was higher than $r_{\text {table }}=0.368$ on taraf $5 \%$. The hypothesis $\left(\mathrm{H}_{0}\right)$ was accepted namely $\mathrm{r}_{\text {count }}>\mathrm{r}_{\text {table }}(0.474>0.368)$. The result showed that there was a significant correlation between students' reading motivation and students' reading comprehension of the grade $X$ students SMA $S$ Nurul 'IlmiPadangsidimpuan in enough category. It has been written in the table of coefficient correlation interpretation below.

Table 2

Categories Value Correlation Coefficient and Degree Correlation

\begin{tabular}{|l|l|}
\hline The value & Degree \\
\hline Between 0.00-0.20 & Very low correlation \\
Between 0.21-0.40 & Low correlation \\
Between 0.41-0.70 & Significant correlation \\
Between 0.71-0.80 & High correlation \\
Between 0.91-1.00 & Very high correlation \\
\hline
\end{tabular}


Testing the truth of significant correlation used the formulate $t_{\text {count }}$.

$$
\begin{aligned}
\mathrm{T}_{\text {count }} & =\frac{r \sqrt{n-1}}{\sqrt{1-r^{2}}}=\frac{0.474 \sqrt{48-1}}{\sqrt{1-0.474^{2}}} \\
& =\frac{0.474 \sqrt{47}}{\sqrt{1-0.224}} \\
& =\frac{0.474(6.855)}{\sqrt{0.776}} \\
& =\frac{3.249}{0.880} \\
& =3.692
\end{aligned}
$$

Based on the calculation above, the researcher found that $t_{\text {count }}=3.692$ and $\mathrm{dk}=\mathrm{N}-2=48-2=46$ and $\mathrm{t}_{\text {table }}$ on taraf significant $1 \%=2.09$. So, $t_{\text {count }}>t_{\text {table }}(3.692>2.09)$. it meant that there was a significant correlation between two variables that it was said that the validity of the contribution of variable $\mathrm{X}$ to variable Y was “accepted”.

To look for the contribution of variable $\mathrm{X}$ to variable $\mathrm{Y}$ as follows:

$$
\begin{aligned}
\mathrm{KP} & =\text { The score of determine coefficient } \\
r \quad & =\text { The score of the coefficients correlation } \\
\mathrm{KP} & =\mathrm{r}^{2} \times 100 \% \\
& =(0.474)^{2} \times 100 \% \\
& =0.224 \times 100 \% \\
& =22 \%
\end{aligned}
$$

Based on calculating above, the contribution variable $\mathrm{X}$ (Reading Motivation) toward variable $\mathrm{Y}$ (Reading Comprehension) there was $22 \%$ and $78 \%$ influenced by other variable.

At the result of this research, the mean score of students' reading motivation was good category and the mean score of students' reading comprehension was enough category. It was assumed that not all students with good reading motivation also have good reading comprehension and not all students with low reading motivation have low reading comprehension. In other words, many students have good reading motivation just for certain book such as reading novel, comic and the interesting book other for them but they have low motivation toward reading text. Then, there are students also have low reading motivation but they have good reading comprehension. So, there are others variable influence the students' reading comprehension, such as reading interest, reading habit, reading 
strategies, and vocabulary mastery. It depends on what factors that influences students to read, as known that reading motivation come from inside and outside.

\section{E. CONCLUSION}

After getting the result of research data, the research came to describe the data as follows:

1. The students' reading motivation of the grade $X$ students SMA S Nurul 'IlmiPadangsidimpuanwas "Good" by getting mean score was 93 .

2. The students' reading comprehension of the grade X students SMA S Nurul 'IlmiPadangsidimpuan was "Enough" by getting mean score was 65.66.

3. Based on the result of data analysis, there was asignificant correlation between reading motivation and reading comprehension of the grade X students SMA S Nurul 'IlmiPadangsidimpuan in enough category. It can be gotten by using the calculating of product moment formula where coefficient correlationlevel $r_{\text {count }}$ was 0.474 and $r_{\text {table }}$ on tarafsignificant $5 \%$ was 0.368 . So, the significant correlation was $0.474>0.368\left(\mathrm{r}_{\text {count }}>\mathrm{r}_{\text {table }}\right)$. Then, on calculating the hypothesis testing has gotten $\mathrm{t}_{\text {count }}$ was3.692 with $\mathrm{dk}=\mathrm{N}-2(48-2=46)$ and $\mathrm{t}_{\text {table }}$ on taraf significant $1 \%$ was 2.09 . So, the significant variables were 3.692>2.09 $\left(\mathrm{t}_{\text {count }}>\mathrm{t}_{\text {table }}\right)$ and the hypothesis $\mathrm{Ha}$ was accepted.

\section{REFERENCES}

AnasSudijono, Pengantar Statistik Pendidikan, Jakarta: PT Raja Grafindo Persada, 2008.

Brown, H. Douglas, Language Assessment: Principles and Classroom Practice, United State Of Francisco: State University, 2004. , Teaching By Principle: An Interactive Approach to Language Pedagogy, USA: Prentice-Hall, Inc., 1994.

Beatrice S. and Mikulecky, More Reading Power, USA: Addison-Wesley Publishing Company, Inc, 1996.

Gay, L. R and Peter Airaisan, Educational Research for Analysis and Application, America: Prentice Hall, 1992.

Gage, N. L. \& David C. Berliner, Educational Psychology, Boston: Houghton Mifflin Company, 1984.

Gambrel, Linda B. and Friends, Assessing Motivation to Read, Vol. 49, No.7, 519.1996, International Reading Association. Accessed on https://goo.gl/2UFcdD, Retrieved on September, $26^{\text {th }} 2017$. 
Hornby, A. S, Oxford Learner's Pocket, New York: Oxford University Press, 2008.

ItaPurnama Sari, The Effect Grammar Transalation Method on Student's Ability In Descriptive Text at Grade X of SMAN 1 Arse, Unpublished Thesis, Padangsidimpuan: IAIN, 2015.

Mohammad Reza Ahmadi, The Correlation Between Students' Reading Motivation and Reading Comprehension, Vol. 4, No.18, 2013, Journal of Educational and Fractice, Accessed from https://goo.gl/h67dfU, Retrieved on September, $26^{\text {th }}$ 2017.

Murniasih, The Correlation Between Students' Motivation in Reading and Their Speed Reading, Jakarta: UIN SyarifHidayatullah, 2013, Accessed from https://goo.gl/Kw8mFd, Retrieved on September, $26^{\text {th }} 2017$.

Nana Sudjana and Ibrahim, PenelitiandanPenilaianPendidikan, Jakarta: SinarbaruAlgesindo, 2002.

Nora Wahyuni, The Correlation between Lectures Teaching Technique and Reading Comprehension at Third Grade of English Education Program (TBI) IAIN Padangsidimpuan, Unpublished Thesis, Padangsidimpuan: IAIN, 2017.

Nunan, David, Practical English Language Teaching, New York: Mc Grow Hill, 2003.

O'Malley, J. Michael \& Lorraine Paldez Pierce, Authentic Assessment for English Language Learners, USA: Addison-Wesley Publishing Company, Inc., 1996.

Oshima, Alice and Ann Hogue, Writing Academic: A Writing and Sentence Structure Workbook For International Students, USA: Addison-Wesley Publishing Company, 1983.

PunajiSetyosari, MetodePenelitiandanPengembangan; EdisiKetiga, Jakarta: Kencana, 2013.

Pardiyono,Pasti Bisa, Teaching Genre Based Writing, Yogyakarta: CV. Andi Offset, 2007

Santrock, John W., Educational Psychology, New York: Mc-Graw Hill, 2004.

SatrioNugroho, Practical English Grammar; Tata BahasaIngrisLengkap, Surabaya: Kartika, 1998.

Scanlone, Early M., eat at. al., Early Intervention For Reading Difficulties: The Interactive Strategies Approach, New York: The Guilford Fress, 2010.

Suharsimi Arikunto, Prosedur Penelitian, Jakarta: Rineka Cipta,2002.

Sugiyono, Statistika untuk Penelitian, Bandung: ALFABETA, 2006.

Tarigan, Hendry Guntur, Membaca Sebagai Suatu Keterampilan Berbahasa, Bandung: Angkasa, 2005.

Westwood, Peter, Reading and Learning Difficulties: Approach To Teaching and Assessment, Australia: Nasional Library of Australia, 2001.

Weir, Cryll J. Communicative Language Testing, New York: Prentice Hall, 1990. 